\title{
PENGARUH VARIABEL EKONOMI MAKRO TERHADAP PENGANGGURAN TERDIDIKDI JAWA TIMUR TAHUN 2010-2014
}

\author{
Oleh: \\ Nur Ravika Famala Sari \\ PT. Bumi Universal Makmur, Surabaya \\ E-mail: ravikafamala2@gmail.com
}

\begin{abstract}
This study aims to determine the effect of Gross Regional Domestic Product, minimum wages district or city, investment, and government expenditure resources to the educated unemployment in East Java. This study uses secondary data for 5 years from 2010-2014. The method of data analysis used in this study is Ordinary Least Square (OLS). The data used in this study is data panel which combines time series and cross section. The results of this study show that partially variables of Gross Regional Domestic Product, minimum wages district or city, domestic investment, and government expenditure significant effect on Educated Unemployment in East Java, while foreign investment no significant effect on Educated Unemployment in East Java. Amount to 70,75\% of the variation of independent variables in this study may explain the variable of educated unemployment in East Java, while the remaining 29,25\% is influenced by other factor outside the model estimation.
\end{abstract}

Keywords :Educated Unemployment, Gross Regional Domestic Product, minimum wages district or city, foreign investment, domestic investment, and government expenditure

\begin{abstract}
ABSTRAK
Penelitian ini bertujuan untuk mengetahui pengaruh dari PDRB, UMK, investasi, dan pengeluaran pemerintah terhadap pengangguran terdidik di Jawa Timur. Penelitian ini menggunakan data sekunder selama 5 tahun dari tahun 2010-2014. Metode analisis data yang digunakan dalam penelitian ini adalah Ordinary Least Square (OLS). Data yang digunakan dalam penelitian ini adalah data panel yaitu gabungan anatara time series dan cross section. Hasil penelitian ini menunjukkan bahwa secara parsial variable PDRB, UMK, PMDN, dan Pengeluaran Pemerintah berpengaruh siginifikan terhadap pengangguran terdidik di Jawa Timur, sedangkan PMA tidak berpengaruh sigifikan terhadap penganggura terdidik di Jawa Timur. Sebesar 70,75\% variasi variable independent dalam penelitian ini dapat menjelaskan variable tingkat pengangguran terdidik di Jawa Timur, sedangkan sisanya 29,25\% dipengaruhi oleh faktor-faktor lain diluar model estimasi.
\end{abstract}

Kata Kunci : Pengangguran Terdidik, PDRB, UMK, PMA, PMDN, dan Pengeluaran Pemerintah 
PENDAHULUAN

Pembangunan ekonomi
adalah suatu proses yang
menyebabkan pendapatan perkapita
penduduk suatu negara meningkat
dalam jangka panjang. Pada dasarnya
pembangunan ekonomi bertujuan
untuk mempercepat proses
pertumbuhan ekonomi, terciptanya
lapangan kerja, mengurangi
pengangguran, memperbaiki tingkat
pendapatan nasional,
meningkatkan kualitas Sumber Daya
Manusia, dimana secara potensial
Indonesia mempunyai kemampuan
sumber daya yang cukup untuk
dikembangkan.

Di sisi lain, dalam meningkatkan kualitas Sumber Daya Manusia, Indonesia dihadapkan oleh berbagai kendala seperti kesempatan kerja yang masih menjadi masalah utama. Hal ini terjadi karena adanya kesenjangan atau ketimpangan untuk mendapatkannya. Kesenjangan antara pertumbuhan angkatan kerja di satu pihak dan kemajuan berbagai sektor perekonomian dalam menyerap tenaga kerja di pihak lain.

$$
\text { Ketimpangan dalam }
$$

mendapatkan kesempatan kerja akan berdampak pada meningkatnya angka pengangguran. Pengangguran di Negara-negara sedang berkembang pada umumnya didominasi oleh pengangguran usia muda dan pengangguran berpendidikan (Todaro dan Smith, 2004).

Pengangguran terdidik merupakan kekurangselarasan antara perencanaan pembangunan pendidikan dengan perkembangan lapangan kerja. Hal tersebut merupakan penyebab utama terjadinya jenis pengangguran ini. Kebanyakan lembaga pendidikan di Negara berkembang hanya menciptakan pencari kerja bukan pencipta kerja (Suryana, 2000). Di sisi lain, pengangguran terdidik ini lebih memilih pekerjaan yang formal yang menempatkan mereka pada posisi tinggi, fasilitas yang nyaman, dan langsung mendapatkan gaji besar.

Jawa Timur merupakan salah satu provinsi yang memberikan kontribusi yang besar terhadap PDB Indonesia. Berdasarkan data BPS, tingkat pengangguran terbuka menurut pendidikan tertinggi yang 
ditamatkan di Jawa Timur tergolong cukup besar. pada tahun 2014 tingkat pengangguran terbuka menurut pendidikan tertinggi yang ditamatkan di Jawa Timur sebesar 4,19\%. Berdasarkan informasi dari Badan Pusat Statistik, tingkat pengangguran terbuka normal di suatu wilayah adalah tidak lebih dari $4 \%$.

PDRB mempunyai pengaruh terhadap jumlah angkatan kerja yang bekerja dengan asumsi apabila PDRB mengalami peningkatan, maka jumlah nilai tambah output dalam seluruh unit ekonomi disuatu wilayah akan meningkat sehingga terjadi peningkatan terhadap jumlah penyerapan tenaga kerja yang diminta atau berorientasi pada padat karya.

Produk Domestik Regional Bruto (PDRB) menurut Badan Pusat Statistik (BPS) didefinisikan sebagai jumlah nilai tambah yang dihasilkan oleh seluruh unit usaha dalam suatu wilayah, atau merupakan jumlah seluruh nilai barang dan jasa akhir yang dihasilkan oleh seluruh unit ekonomi di suatu wilayah. Angka PDRB dapat diperoleh melalui tiga pendekatan yaitu pendekatan produksi, pendekatan pendapatan dan pendekatan pengeluaran.

Upah juga mempunya pengaruh terhadap penyerapan tenaga kerja. Jika semakin tinggi tingkat upah yang ditetapkan, maka berpengaruh pada meningkatnya biaya produksi, akibatnya untuk melakukan efisiensi, perusahaan terpaksa melakukan pengurangan tenaga kerja, yang berakibat pada tingginya pengangguran. Penurunan jumlah tenaga kerja yang dibutuhkan karena pengaruh turunnya skala produksi disebut dengan efek skala produksi atau scale effect. penurunan jumlah tenaga kerja yang dibutuhkan karena adanya pergantian / penambahan penggunaan mesinmesin disebut efek substitusi (Sudarsono, 1988).

Peningkatan ketersediaan lapangan pekerjaan guna menyerap banyak tenaga kerja juga dipengaruhi oleh besarnya investasi. Tapi pada kenyataanya sekarang investasi banyak bergerak di sektor jasa dan sektor padat modal. Sehingga pertumbuhan ekonomi hanya meningkat pada presentasenya saja 
tanpa diikuti dengan penyerapan tenaga kerja.

Kegiatan investasi

memungkinkan suatu masyarakat terus menerus meningkatkan

kegiatan ekonomi dan kesempatan kerja, meningkatkan pendapatan nasional dan meningkatkan taraf kemakmuran masyarakat. Dalam perekonomian makro kenaikan investasi akan meningkatkan permintaan agregat dan pendapatan nasional. Peningkatan dalam permintaan agregat tersebut akan membawa peningkatan pada kapasitas produksi suatu perekonomian yang kemudian akan diikuti oleh pertambahan dalam kebutuhan akan tenaga kerja untuk proses produksi, yang berarti peningkatan dalam kesempatan kerja (Wafi Lestari, 2011).

Dilihat dari sisi pengeluaran pemerintah yang dipergunakan untuk membeli barang dan jasa akan mendorong terciptanya lapangan kerja. Lapangan kerja yang tersedia akibat dari aktivitas pemerintah akan dipengaruhi oleh jenis pengeluaran. Pengeluaran pemerintah yang tidak tepat sasaran, misalnya pengeluaran pembangunan lebih banyak ditujukan untuk membiayai proyek-proyek yang padat modal sehingga pengeluaran pemerintah menjadi tidak tepat sasaran dan jumlah pengangguran terbuka setiap tahunnya bertambah (Rizka Juita Rachim, 2013)

Adapun tujuan yang ingin di capai melalui penelitian ini adalah untuk mengetahui seberapa besar pengaruh PDRB, UMK, Investasi, dan Pengeluaran Pemerintah Terhadap Pengangguran Terdidik di Jawa Timur pada tahun 2010-2014.

\section{METEDOLOGI PENELITIAN}

Lokasi penelitian terletak diprovinsi Jawa Timur. Provinsi Jawa Timur merupakan salah satu Provinsi penyumbang PDB terbesar ke-2 setelah DKI Jakarta. Peneliti memilih lokasi ini karena dibalik angka pertumbuhan ekonomi yang tinggi, pengangguran terbuka berdasarkan tingkat pendidikan di JawaTimur juga termasuk kategori tinggi karena rata-rata tingkat pengangguran terbuka kabupaten/kota di Jawa Timur lebih dari $4 \%$.

Dalam penelitian ini menggunakan pendekatan kuantitatif 
yang menekankan analisisnya pada data-data numerikal (angka) yang diolah dengan metode statistika. Pada dasarnya, pendekatan kuantitatif dilakukan pada penelitian inferensial (dalam rangka pengujian hipotesis) dan menyandarkan kesimpulan hasilnya pada suatu probabilitas kesalahan penolakan hipotesis nihil. Dengan metode kuantitatif akan diperoleh signifikansi perbedaan kelompok atau signifikansi hubungan antar variabel yang diteliti.

Data yang digunakan dalam penelitian ini adalah data sekunder. Data sekunder adalah data yang dikumpulkan, diolah, dan disajikan oleh pihak lain, yang biasanya dalam bentuk publikasi atau jurnal yang diperoleh dari Disnakertransduk Provinsi Jawa Timur, BPS Provinsi Jawa Timur, Badan Penanaman Modal (BPM) Provinsi Jawa Timur, Direktorat Jendral Perimbangan Keuangan, Departemen Keungan. Penelitian ini menggunakan metode kuantitatif dengan alat analisis regresi berganda dengan menggunakan eviews. Analisis regresi berganda digunakan untuk menguji pengaruh PDRB, Upah Minimum Kabupten/kota, Investasi, dan Pengeluaran Pemerintah terhadap Jumlah Pengangguran Terdidik di Jawa Timur. Seberapa besar variable tersebut saling mempengaruhi yaitu dapat dihitung dengan menggunakan persamaan regresi linier berganda.

\section{Analisis Data dan Uji Hipotesis}

Data yang digunakan dalam penelitian ini adalah data panel. Data panel adalah data yang diperoleh dengan menggabungkan antara cross section dan data time series. Data cross section dalam peneltian ini adalah data dari 38 Kabupaten/Kota di Jawa Timur, sedangkan data time series dalam penelitian ini adalah data tahun 2010 sampai dengan tahun 2014.

Model Regresi linier berganda dengan data panel semi log yang digunakan adalah sebagai berikut:

$Y=a+b_{1} \log X_{1}+b_{2} \log X_{2}+b_{3} \log X_{3}+b_{4} l$ og $X_{4}+e$

Keterangan :

$Y \quad=$ Tingkat Pengngguran Terdidik

$a \quad=$ koefisien konstanta 


$$
\begin{array}{ll}
b_{1} b_{2} b_{3} b_{4} & =\text { koefisien garis regresi } \\
X_{1} & =\text { Variabel PDRB } \\
X_{2} & =\text { Variabel Upah } \\
X_{3} & =\text { Variabel Investasi } \\
X_{4} & =\text { Variabel Pengeluaran } \\
& \text { Pemerintah }
\end{array}
$$

\section{Uji Simultan (Uji F)}

Pengujian dilakukan secara bersama-sama variabel independen berpengaruh secara signifikan atau tidak terhadap variabel dependen. Pengujian ini dilakukan uji satu arah dengan hipotesa:

Ho : artinya tidak terpengaruh secara signifikan dari variabel independen terhadap variabel dependen secara bersamasama.

$\mathrm{Ha}$ : artinya terdapat pengaruh signifikan dari variable independen terhadap variabel dependen secara bersamasama.Kriteria pengujian:

Ho diterima dan Ha ditolak apabila $\mathrm{F}_{\text {hitung }}<\mathrm{F}_{\text {tabel, }}$ artinya variabel independen tidak berpengaruh secara signifikan terhadap variabel dependen.

Ho ditolak dan $\mathrm{Ha}$ diterima apabila $F_{\text {hitung }}>F_{\text {tabel, }}$ artinya variabel independen berpengaruh secara

signifikan terhadap variabel
dependen.

\section{Uji Parsial (Uji T)}

Pengujian dilakukan untuk mengetahui secara partial apakah variabel independen berpengaruh secara signifikan atau tidak terhadap variabel independen. Pengujian ini dilakukan dengan uji dua arah dengan hipotesa:

Ho : artinya tidak terpengaruh secara signifikan dari variabel independen terhadap variabel dependen.

$\mathrm{Ha}$ : artinya ada pengaruh secara signifikan dari variabel independen terhadap variabel dependen.

Dengan kriteria peng ujian:

Ho diterimadan Ha ditolak apabila $\mathrm{t}_{\text {hitung }}<\mathrm{t}_{\text {tabel, }} \quad$ artinya variable independen tidak berpengaruh secara signifikan terhadap variable dependen.

Ho ditolak dan Ha diterima apabila $\mathrm{t}_{\text {hitung }}>\mathrm{t}_{\text {tabel, }} \quad$ artinya variable independen berpengaruh secara signifikan terhadap variable dependen.

\section{Koefisien Determin}

Koefisien determinasi 
menggambarkan tingkat hubungan antara satu atau beberapa variabel bebas dengan terikat. $\mathrm{R}^{2}$ merupakan besaran non negatif, batasnya adalah $0 \leq R^{2} \leq 1$. Suatu $R^{2}$ sebesar 1 berarti terjadi hubungan sempurna, sedangkan $\mathrm{R}^{2}$ yang bernilai 0 berarti tidak ada hubungan antara variabel terikat dengan variabel bebas, dengan demikian semakin kecil $\mathrm{R}^{2}$ semakin lemah hubungan antar variabel.

\section{PEMBAHASAN}

\section{Pengangguran Terdidik}

Angka TPT menurut tingkat pendidikan tertinggi yang ditamatkan (SMA ke atas) Jawa Timur Tahun 2014 mengalami kenaikan yang cukup signifikan, jika diamati menurut tingkat pendidikannya menunjukkan bahwa semakin tinggi tingkat pendidikan yang ditamatkan maka angka pengangguran juga meningkat.

Pengangguran terdidik salah satu masalah di Jawa Timur, yang menjadi masalah serius adalah bagaimana pengangguran yang ada ini bukan cuma pengangguran yang memang tidak lanjut sekolah karena ketiadaan biaya tapi yang memprihatinkan adalah mereka yang tidak bekerja tetapi latar belakang pendidikan mereka tinggi atau lulusan akademi atau universitas.

Tabel 1. Perkembangan Tingkat Pengangguran Terdidik di Jawa Timur Tahun 2010-2014

\begin{tabular}{cccc}
\hline Tahun & $\begin{array}{c}\text { Jumlah Pengangguran } \\
\text { (SMA Keatas) }\end{array}$ & $\begin{array}{c}\text { Angkatan } \\
\text { Kerja }\end{array}$ & $\begin{array}{c}\text { Tingkat } \\
\text { Pendidikan (\%) }\end{array}$ \\
\hline $\mathbf{2 0 1 0}$ & 481565 & 5227716 & 9.21 \\
\hline $\mathbf{2 0 1 1}$ & 378253 & 5427904 & 6.97 \\
\hline $\mathbf{2 0 1 2}$ & 411118 & 5648025 & 7.28 \\
\hline $\mathbf{2 0 1 3}$ & 448109 & 5948691 & 7.53 \\
\hline $\mathbf{2 0 1 4}$ & 465686 & 3939503 & 11.82 \\
\hline
\end{tabular}

Sumber: Disnaker Provinsi Jawa Timur (data diolah)

Produk Domestik Regional Bruto (PDRB)

PDRB menjadi salah satu indikator yang digunakan untuk mengukur kegiatanekonomi di suatu
wilayah.Perekonomian di suatu wilayah dikatakan tumbuh dan berkembang jika barang dan jasa yang diproduksi pada periode ini lebih besar dibandingkan periode 
sebelumnya, yang kemudian diturunkan menjadi nilai tambah.

Selama periode $2010-2014$

tidak ada pergeseran peringkat PDRB kabupaten/kota di Jawa Timur.Beberapa kabupaten/kota mengalami peningkatan kontribusi, diikuti penurunan kontribusi kabupaten/kota lainnya.12 kabupaten/kota mengalami peningkatan kontribusi, dan 26 kabupaten/kota lainnya menurun kontribusinya terhadap total 38 kabupaten/kota. Kota Surabaya meningkat kontribusinyadari 23,34 persen pada tahun 2010 menjadi 24,18 persen pada tahun 2014; Kabupaten Sidoarjo meningkat dari 8,22 persen menjadi 8,41 persen; Kabupaten Gresik meningkat dari 5,96 persen menjadi 6,05 persen. Sementara itu, Kabupaten Pasuruan menurun kontribusinya dari 6,18 persen menjadi 6,33 persen.

\section{Upah Minimum Kabupaten/Kota}

Berdasarkan UMK Peningkatan upah minimum sebenarnya dapat mempengaruhi tamatan perguruan tinggi yang lulus untuk masuk di pasar tenaga kerja, sehingga jumlah angkatan kerja pada kelompok tersebut semakin meningkat dan dengan sendirinya akan meningkatkan jumlah TPAK, namun peningkatan TPAK yang diakibatkan dari peningkatan upah minimum yang terlalu cepat dan tinggi yang tidak diikuti dengan laju pertumbuhan lapangan kerja maka akan berpotensi meningkatkan jumlah pengguran terdidik.

pergerakan upah minimum Kabupaten/Kota di Jawa Timur terus mengalami kenaikan setiap tahunnya dan dari tahun ke tahun kota Surabaya memiliki UMK tertinggi yaitu pada tahun 2014 sebesar Rp. 2.200.000,00 dan UMK terendah terdapat pada Kabupaten Pacitan, Ponorogo, Trenggalek, Magetan, dan Kota Blitar sebesar Rp. 1.000.000,00. Hal ini menunjukan bahwa Kota Surabaya memiliki biaya hidup yang relatif lebih tinggi dibanding dengan Kabupaten/Kota lainnya hal ini ditunjukan dengan nilai upah minimum tertinggi setiap tahunnya dan didasarkan dan disesuaikan pada kebutuhan hidup layak (KHL) Kota Surabaya.

\section{Investasi}


Dalam kegiatan investasi di Indonesia, dikenal adanya Penanaman Modal Dalam Negeri (PMDN) dan Penanaman Modal Asing (PMA). Masuknya invetasi ke Jawa Timur diharapkan mampu menyerap banyak tenaga kerja. Dari data Badan Penanaman Modal Provinsi Jawa Timur mencatat, total relaisasi investasi PMDN mencapai Rp. 34,85 Triliyun di 234 Proyek pada tahun 2013 dan mampu menyerap 52.530 tenaga kerja. total relaisasi investasi PMA mencapai Rp. 33,6 Triliyun di 278 Proyek pada tahun 2013 dan mampu menyerap 477.466 tenaga kerja.

\section{Pengeluaran Pemerintah}

$$
\begin{aligned}
& \text { Pengeluaran pemerintah } \\
& \text { terbagi menjadi dua yaitu } \\
& \text { pengeluaran langsung dan } \\
& \text { pengeluaran tidak langsung yang } \\
& \text { biasa juga disebut dengan } \\
& \text { pengeluaran rutin dan pembangunan, } \\
& \text { dimana pengeluaran ritun yaitu } \\
& \text { belanja pemerintah untuk menunjang } \\
& \text { jalannya pemerintah seperti belanja } \\
& \text { pegawai dan belanja barang dan jasa. } \\
& \text { Berdasarkan data dari } \\
& \text { Direktorat Jendral Perimbangan } \\
& \text { Keuangan, Kementrian Kuangan, }
\end{aligned}
$$

perkembangan pengeluaran pemerintah baik belanja langsung maupun tidak langsung menunjukkan masing-masing daerah kabupaten/kota mengalami kenaikan jumlah pengeluaran seperti Kota Surabaya dari Rp. 4.185.867.400.411 pada tahun 2010 secara terus menerus naik hingga pada tahun 2014 menjadi Rp. 6.636.186.508.258. Kota Surabaya memiliki pengeluaran pemerintah tertinggi diantara kabupaten/kota lainnya.

Dalam melakukan analisis data pengaruh PDRB, UMK, Invstasi, dan Pengeluaran Pemerintahterhadap pengangguran terdidik di Jawa Timur tahun 20102014 menggunakan analisis regresi data panel yaitu data yang menggabungkan antara metode regresi time series dan cross section. Dengan menggunakan data panel dapat mengidentifikasi hubungan antara variabel bebas dan variabel terikat secara akurat. Pengujian data panel cukup dengan uji Statistik F, Uji Statistik t, dan uji Koefisien Determinasi $\left(\mathrm{R}^{2}\right)$ tanpa melakukan uji asumsi klasik. 
Model yang tepat untuk Effect di bawah ini ditunjukkan digunakan dalam penelitian ini persamaan regresi data panel PDRB, adalah model OLS (Common UMK, Investasi, dan Pengeluaran Effect).Dalam penelitian Common Pemerintah.

\section{Tabel 2. Hasil Common Effect (Pooled Least Square)}

Dependent Variable: PT?

Method: Pooled Least Squares

Date: 08/10/16 Time: 00:39

Sample: 20102014

Included observations: 5

Cross-sections included: 38

Total pool (balanced) observations: 190

\begin{tabular}{lrlrr}
\hline \hline \multicolumn{1}{c}{ Variable } & Coefficient & Std. Error & t-Statistic & \multicolumn{1}{c}{ Prob. } \\
\hline C & -3.359885 & 0.874969 & -3.840007 & 0.0002 \\
PDRB? & -0.378569 & 0.156033 & -2.426213 & 0.0162 \\
UPAH? & 0.470933 & 0.059367 & 7.932615 & 0.0000 \\
\multicolumn{1}{c}{ INVESTASI? } & 0.003817 & 0.003020 & 1.263883 & 0.2079 \\
\multicolumn{1}{c}{ PP? } & 0.543435 & 0.109869 & 4.946230 & 0.0000 \\
\hline \hline R-squared & 0.700785 & Mean dependent var & 3.918895 \\
Adjusted R-squared & 0.694315 & S.D. dependent var & 0.349610 \\
S.E. of regression & 0.193295 & Akaike info criterion & -0.423238 \\
Sum squared resid & 6.912129 & Schwarz criterion & -0.337790 \\
Log likelihood & 45.20758 & Hannan-Quinn criter. & -0.388624 \\
F-statistic & 108.3211 & Durbin-Watson stat & 0.996528 \\
Prob(F-statistic) & 0.000000 & & \\
\hline \hline
\end{tabular}

Sumber : Eviews 9 data diolah

\begin{abstract}
Koefisien PDRB memiliki dampak negatif terhadap pengangguran terdidik (Y) sebesar 0.378569. Jika PDRB (X1) naik sebesar $1 \%$ maka jumlah pengangguran terdidik akan turun sebesar -0.378569 .
\end{abstract}

PDRB $\left(\mathrm{X}_{1}\right)$ memiliki nilai $\mathrm{t}_{\text {hitung }}$ sebesar -2.426213 dengan nilai probabilitas sebesar 0.0162 . Hal ini menunjukkan bahwa nilai $t_{\text {hitung }}$ (- $2.426213)<\mathrm{t}_{\text {tabel }}(-1.97260)$ dan nilai probalitas $0.0162<\alpha=0.05$, maka $\mathrm{H}_{0}$ ditolak dan $\mathrm{H}_{\mathrm{a}}$ diterima. Dengan demikian dapat disimpulkan bahwa variabel PDRB $\left(\mathrm{X}_{1}\right)$ secara individual berpengaruh signifikan terhadap Pengangguran Terdidik di Jawa Timur.

Kenaikan PDRB akan menurunkan jumlah pengangguran terdidik di Jawa Timur. Besarnya 
PDRB di Jawa Timur itu sendiri didukung oleh sektor industri yang memiliki peningkatan tertingg PDRB setiap tahunnya. Perluasan industri itu sendiri akan meningkatkan output dan didukung dengan pertumbuhan ekonomi yang lebih berifat padat karya sehingga banyak menciptaka lapanga kerja baru.

Koefisien UMK memiliki dampak positif terhadap pengangguran terdidik (Y) sebesar 0.470933. jika UMK (X2) naik sebesar $1 \%$ maka jumlah pengangguran terdidik akan naik sebesar 0.470933 .

UMK $\left(\mathrm{X}_{2}\right)$ memiliki nilai $t_{\text {hitung }}$ sebesar 7.932615dengan nilai probabilitas sebesar 0.0000 . Hal ini menunjukkan bahwa nilai $t_{\text {hitung }}(7.932615)>t_{\text {tabel }}(1.97260)$ dan nilai probalitas $0.0000<\alpha=0.05$, maka $\mathrm{H}_{0}$ ditolak dan $\mathrm{H}_{\mathrm{a}}$ diterima. Dengan demikian dapat disimpulkan bahwa variabel UMK $\left(\mathrm{X}_{2}\right)$ secara individual berpengaruh signifikan terhadap Pengangguran Terdidik di Jawa Timur.

Jumlah angakatan kerja menurut pendidikan tertinggi yang ditamatkan pada masa kini cenderung kurang memiliki keterampilan, mereka tidak mampu menciptakan lapangan kerja sendiri sehingga harus bersaing dengan angkatan kerja lain dan dengan adanya UMK pengusaha akan lebih berhati- hati dalam menerima para pekerja dan hanya para pekerja yang memiliki kemampuan dan keterampilan yang baik yang akan mereka pilih sehingga banyak para pekerja yang tidak berkualitas yang tidak dapat bekerja sesuai dengan yang diharapkan dan justru meningkatkan jumlah pengangguran terdidik.

Koefisien Investasi memiliki dampak positif terhadap pengangguran terdidik (Y) sebesar 0.003817. jika Investasi (X3) naik sebesar $1 \%$ maka jumlah pengangguran terdidik akan naik sebesar 0.003817 .

Investasi $\left(\mathrm{X}_{3}\right)$ memiliki nilai $\mathrm{t}_{\text {hitung }}$ sebesar 1.263883 dengan nilai probabilitas sebesar0.2079. Hal ini menunjukkan bahwa nilai $\mathrm{t}_{\text {hitung }}(1.263883)<\mathrm{t}_{\text {tabel }}(1.97260)$ dan nilai probalitas $0.2079>\alpha=0.05$, maka $\mathrm{H}_{0}$ diterima dan $\mathrm{H}_{\mathrm{a}}$ ditolak. Dengan demikian dapat disimpulkan 
bahwa variabel Investasi $\left(\mathrm{X}_{3}\right)$ secara individual tidak berdampak signifikan terhadap Pengangguran Terdidik di Jawa Timur.

Investasi berpengaruh positif dan tidak signifikan terhadap pengangguran terdidik. Hal ini disebabkan investasi lebih banyak dialokasikan untuk investasi padat modal bukan untuk padat karya, sehingga kurang adanya pemberdayaan tenaga kerja. Bahkan sering dijumpai dana investasi dipakai untuk membeli mesin industri sebagai pengganti tenaga manusia dalam proses produksi. Penggantian tenaga manusia oleh mesin produksi akan mengurangi peran tenaga manusia dalam proses produksi, hal ini mengakibatkan pengurangan tenaga kerja.

Koefisien Pengeluaran Pemerintah memiliki dampak positif terhadap pengangguran terdidik (Y) sebesar 0.543435. Jika Pengeluaran Pemerintah (X4) naik sebesar 1\% maka jumlah pengangguran terdidik akan naik sebesar 0.543435

Pengeluaran Pemerintah $\left(\mathrm{X}_{4}\right)$ memiliki nilai $t_{\text {hitung }}$ sebesar 4.946230 dengan nilai probabilitas sebesar 0.0000. Hal ini menunjukkan bahwa nilai $t_{\text {hitung }}(4.946230)>t_{\text {tabel }}$ (1.97260) dan nilai probalitas $0.0000<\alpha=0.05$, maka $\mathrm{H}_{0}$ ditolak dan $\mathrm{H}_{\mathrm{a}}$ diterima. Dengan demikian dapat disimpulkan bahwa variabel Pengeluaran Pemerintah $\left(\mathrm{X}_{4}\right)$ secara individual berpengaruh signifikan terhadap Pengangguran Terdidik di Jawa Timur.

Pengeluaran Pemerintah berpengaruh positif dan signifikan terhadap pengangguran terdidik. Artinya bahwa apabila terjadi peningkatan pada pengeluaran pemerintah, maka jumlah pengangguran terdidik juga akan meningkat. Pemerintah provinsi Jawa Timur sedang membangun berbagai macam kebutuhan public untuk kalangsungan perekonomian daerah, namun hal ini masih dalam tahap pembangunan, sehingga belum memberikan kontribusi besar terhadap penyerapan tenaga kerja di Jawa Timur.

Berdasarkan hasil regresi didapatkan nilai koefisien determinasi $\left(\mathrm{R}^{2}\right) \quad$ sebesar 0.700785atau sebesar 70,07\%. Hal ini menunjukkan bahwa kemampuan 
variabel bebas untuk menjelaskan variabel terikat adalah sebesar 0.700785atau 70,07\%. sedangkan untuk sisanya sebesar $29,93 \%$ dijelaskan oleh variabel lain di luar model yang secara implisit tercermin pada variabel pengganggu.

\section{KESIMPULAN}

Secara Parsial Variabel PDRB berpengaruh negatif dan signifikan terhadap Pengangguran Terdidik di Jawa Timur dengan nilai koefisien sebesar -0,378569. UMK dan Pengeluaran Pemerintah berpengaruh Positif dan signifikan terhadap Pengangguran Terdidik di Jawa Timur dengan koefisien masingmasing yaitu 0,470933 dan 0.543435 . Variabel Investasi tidak berpengaruh signifikan terhadap pengangguran terdidik di Jawa Timur dengan nilai koefisien sebesar 0,003817 .

\section{Setelah dilakukannya} pengujian dan pembahasan mengenai Pengangguran Terdidik di Jawa Timur, maka ada beberapa saran dari peneliti yaitu, Berasarkan hasil penelitian, Pengeluaran Pemerintah mempunyai pengaruh paling besar diantara variabel lain. Pengeluaran
Pemerintah terbukti berpengaruh positif terhadap Pengangguran Terdidik di Jawa Timur, sehingga Pemerintah Provinsi JawaTimur diharapkan lebih mengawasi dalam pengalokasian dana. Untuk mengurangi tingkat pengangguran terdidik di Jawa Timur maka mobilitas atau pembangunan ekonomi melalui pengeluaran pemerintah seharusnya diarahkan menuju daerah yang mempunyai pengangguran terdidik yang tinggi, atau daerah dengan perekonomian yang rendah dan berorientasi pada padat karya. Sektor sekunder dan tersier harus lebih dipacu produktivitasnya. Pengeluaran Pemerintah dapat di distribusikan pada sektor-sektor yang lebih produktif guna meningkatkan output sehingga banyak menyerap tenaga kerja.

\section{DAFTAR PUSTAKA}

Badan Pusat Statistik. 2014. Keadaan Angkatan Kerja di Jawa Timur, Surabaya, h.24

Badan Pusat Statistik. 2012. Keadaan Angkatan Kerja di Jawa Timur, Surabaya, h.24 
Pengaruh Variabel Ekonomi Makro Terhadap........(Nur Ravika Famala Sari)

Badan Pusat Statistik. 2011. Keadaan Angkatan Kerja di Jawa Timur, Surabaya, h.24

Badan Pusat Statistik. 2010. Keadaan Angkatan Kerja di Jawa Timur, Surabaya, h.24

Badan Pusat Statistik, 2015. Produk Domestik Regional Bruto Kbupaten/Kota Menurut Lpangan Usaha (PDRB) 2010-2014, Surabaya, hal.26

Julita Rachim, Rizka. 2013. Analisis

Pengaruh Upah Minimum

Provinsi, Pengeluaran

Pemerintah, Investasi Swasta

Dan Jumlah Penduduk

Terhadap Pengangguran

Terbuka Di Provinsi Sulawesi

Selatan Periode 1996-2010,

Universitas Hasanuddin

1980-2011, Jurnal Ekonomi

Pembangunan, Vol 2 (3) 2013

P. Todaro, Michael dan C. Smith,

Stephen. 2008. Pembangunan

Ekonomi, Erlangga
Sukirno, Sadono, 2012. Makro Ekonomi: Teori Pengantar, Rajawali Press

Sukirno, Sadono, 1994. Pengantar Teori Ekonomi Makro. Jakarta: PT Raja Grafindo

Suryana. 2000. Ekonomi Pembangunan : Problematika dan pendekatan, Salemba empat

Sudarsono. 1998. Pengantar Ekonomi Mikro, Jakarta: LP3ES

Wafi Lestari, Ayu. 2011. Pengaruh Jumlah Usaha, Nilai Investasi Dan Upah Minimum Terhadap Permintaan Tenaga Kerja Pada Industry Kecil Dan Menengah Di Kabupaten Semarang. Skripsi: Unversitas Diponegoro 